\title{
ASSESSMENT OF HEAVY METALS IN GREEN VEGETABLES AND CEREALS COLLECTED FROM JAMKHANDI LOCAL MARKET, BAGALKOT, INDIA.
}

\author{
N. Shobha ${ }^{1}$ and B. M. Kalshetty ${ }^{2, *}$ \\ ${ }^{1}$ Research and Development center, Bharathiar University Coimbatore, \\ Tamil-Nadu, India. \\ ${ }^{2}$ B. L. D. E'S Science College Jamkhandi, District Bagalkot, Karnataka State, India. \\ *E-mail: drkalshetty@gmail.com
}

\begin{abstract}
Heavy metals determination in Cereals and vegetables is of vital interest because of their essential or toxic nature. In order to assess the levels and impact of different trace metals on human health, a study was carried out to determine the levels of different trace heavy metals present in commonly edible cereals and vegetables which are available in the local market of Jamkhandi City. Industrial effluents, domestic waste, municipal sewage water, agricultural runoff -significantly affected the water quality on short- and long -term basis. The present investigation reveals with the assessment of heavy metals in soils, selected cereals and green vegetables available in the region irrigated with contaminated water. All the samples were analyzed using Flame photometer (Elico), Atomic Absorption Spectrophotometer (Elico). The concentrations of most of the heavy metals were found in the normal legal limit in irrigation water, soil samples and food set as compared with international regulations. The obtained results declared that concentrations of metals were exceeding than the recommended maximum acceptable levels. The concentration of heavy metals in wheat gains of lands was found to be in the order of $\mathrm{Cu}>\mathrm{Zn}<\mathrm{Ni}<\mathrm{Cd}$. Other grains and green vegetables were analyzed for heavy metals such as $\mathrm{Mn}, \mathrm{Pb}$, and $\mathrm{Fe}$, all were beyond recommended dietary limits. It is recommended that treatment facility must be installed to reduce heavy metals concentrations of waste water being used for downstream irrigation. The study suggests that contaminated water irrigation led to the accumulation of heavy metals in foodstuff causing potential health problems for consumers.
\end{abstract}

Keywords: Heavy metals, Cereals, Green vegetables, Municipal wastewater and industrial effluents.

(1) RASĀYAN. All rights reserved

\section{INTRODUCTION}

Heavy metal contamination in cereals and vegetables cannot be underestimated as these foodstuffs are important components of the human diet. The cereals most commonly cultivated in this region are wheat, Jawar, Barley, Sorghum, Rice, Sajji etc. These cereals are the important as well as very nutrient grains. Also is more stable food for most people of the area. Cereals are needed for a healthy diet because cereals derived products are recommended due to their contents such as fiber, trace minerals, and vitamins, which support to prevent various diseases. But, Heavy metals contamination in food products more than tolerance limit leads adverse effect on health. The cereals are rich in carbohydrates, protein etc., and act as sources of energy. Therefore, they are essential and useful for a well-balanced healthy diet. Vegetables are rich sources of vitamins, minerals, and fibers, and also have beneficial antioxidative effects. However, intake of heavy metal-contaminated vegetables may pose a risk and pose a direct threat to the human health. Heavy metal contamination of the food items is one of the most important aspects of food quality assurance $^{1,2}$.

\section{Food safety and potential health risks}

Rapid and unorganized urban and industrial developments have contributed to the elevated levels of heavy metals in the urban environment of developing countries such as Egypt ${ }^{3}, \operatorname{Iran}^{4}, \mathrm{China}^{5} \mathrm{and} \mathrm{India}^{6}$. In urban and peri-urban areas, land contamination with toxic metals is common as a result of the industrial and municipal activity. Wastewater irrigation to increase the yield of food crops (vegetables) is the

Rasayan J. Chem., 10(1), 124-135 (2017)

http://dx.doi.org/10.7324/RJC.2017.1011575 
principal source of contamination in urban agricultural lands ${ }^{7}$. These effluents are rich in toxic metals and are a chief contributor to metals loading in waste irrigated and amended soils ${ }^{8,9}$. Emissions of heavy metals from the industries and vehicles may be deposited on the vegetable surfaces during their production, transport and marketing. Recently, have reported that atmospheric deposition can significantly elevate the levels of heavy metals contamination in vegetables commonly sold in the markets of Varanasi ${ }^{6}$, India.

Heavy metals are among the major contaminants of food and may be a major problem to environment ${ }^{3,10}$. The heavy metals may enter the human body through consumption of contaminated drinking water, consumption of food plants, cereals and green vegetables grown in the metal contaminated soil and sediments ${ }^{10}$. Heavy metals are potential environmental contaminants of causing human health problems if present in a higher percentage of the food grains. The heavy metals showed toxic effects even at very low concentration ${ }^{11}$. Heavy metals are non-biodegradable and persistent, have long biological half-lives and they can be bioaccumulated through the biological chains. Soil - plants, green vegetables and food leading to unwanted side effects. The high amount of heavy metals in environment represents a potential danger to human health due to their extreme toxicity. Heavy metal contamination may be occurred due to the irrigation with contaminated water from municipal wastes, industrial effluents, the addition of inorganic fertilizers, metal based pesticides and agricultural practices. Crops and green vegetables grown in soils contaminated with heavy metals have a greater accumulation of heavy metals than those grown in uncontaminated soil ${ }^{12}$.Many researchers emphasized the toxic effects of heavy metals to the human body. The elements such as $\mathrm{Cd}, \mathrm{Cr}$ and Arsenic are considered as carcinogenic (cancer producing elements), while $\mathrm{Fe}, \mathrm{Cu}, \mathrm{Zn}, \mathrm{Ni}$ and $\mathrm{Mn}$ are considered as essential elements. But, these elements are found in higher than their permissible limits may create a toxic effect in human ${ }^{13,14}$.

\section{Metal Toxicity and Health Risk}

Lead toxicity in the body can cause - musculoskeletal, renal, ocular, immunological, neurological, reproductive and developmental effects. Cadmium intake is known to result in bone fracture, cancer, diarrhea, stomach pains, severe vomiting, reproductive failure and damage to thecentral nervous system. In addition to this cardiovascular, kidney, nervous as well as bone disease ${ }^{15,16}$. Heavy metals have also been implicated in causing carcinogenesis, mutagenesis and tetra genesis ${ }^{17}$. A complete profile of heavy metals in foodstuffswas not published so far. Thus, the aim of this study was therefore to evaluate and compare the concentrations of heavy metals in cereals available in the local markets for the consumers in Jamkhandi city and causing health hazardous with the consumption of these cereals.

Vegetables are of great importance in the diet because of the presence of vitamins and mineral salts. In addition to this green vegetables contain water, calcium, iron, sulfur and potash ${ }^{18}$. Vegetables are very important protective food and useful for the maintenance of health and the prevention and treatment of various diseases ${ }^{19}$. The elements like $\mathrm{Cd}, \mathrm{Pb}$, and $\mathrm{Hg}$ will cause a major problem to our environment while the elements like $\mathrm{Cu}, \mathrm{Zn}, \mathrm{Fe}$, Sulphur and $\mathrm{Mn}$ are essential for biochemical reactions in the body ${ }^{20}$. Generally, most of the heavy metals are not biodegradable, have long biological half-lives and have the potential for accumulation in the different body organs leading to unwanted side effects ${ }^{16}$.

The toxicity of metal ions is correlated to one another; the Copper toxicity induces iron deficiency, lipid peroxidation and destruction of membranes ${ }^{20}$. High level of Nickel may result in Zinc or Iron deficiency as well as enzymic malfunctioning ${ }^{16}$. Based on persistent nature, accumulation behavior and the probability of potential toxicity effects of heavy metals as a result of consumption of green vegetables and food grains. Hence, there is need to assess trace elements present in food grains and green vegetables and some recommendations were made to human diet.

\section{Study Area}

The study was conducted on food grains, vegetables from the local market of Jamkhandi city (taluk place of Bagalkot district) river water quality, soil properties were investigated from the four villages of Jamkhandi taluk viz; Hipparagi, Surapali, Savalagi and Hire Padasalagi, all these villages are located on or along the Krishna river belt. The cereals and vegetables are exporting daily or seasonally to the Jamkhandi marketplaces. 


\section{RASĀYAN J. Chem.}

Vol. 10 | No. 1 |124-135 | January - March | 2017

\section{EXPERIMENTAL}

\section{Materials and Methods}

All the reagents used for analytical grade highly purified de-ionized double distilled water (DDW) was used for dilution and preparation of reagents and working standards. All glass wares, plastic wares used, were thoroughly washed with liquid soap, rinsed with distilled water, soaked in $10 \%$ nitric acid for 24 hours, once again cleaned thoroughly with DDW and dried in such a manner to ensure that any contamination does not occur. All collected samples were stored in clean polyethylene bags, and used for analyses.

\section{Sampling and sample preparation}

For soil sampling, four random bowls of cereal fields were selected (Hipparagi- spot S1, Surapali-Spot S2,Savalagi-spot S3 and Hire Padasalagi-spot S4) at a mutual distance of about 20 feet were collected from the surface, at the same period water samples were collected to know their Physico-chemical parameters. The soil samples were oven dried overnight at $80-90^{\circ} \mathrm{C}$, gently ground and sieved to $2 \mathrm{~mm}$ mesh size, homogenized, and used for heavy metal and other parameters analysis. At harvest time, cereal samples were collected from each field and washed with DDW to remove the adhered soil, dust and other contaminants. The selected cereals were oven dried for 48 hours at $70^{\circ} \mathrm{C}$ and then ground to pass a $1 \mathrm{~mm}$ sieve for determination of heavy metal contents.

A total of six samples of vegetable were purchased from the central place of Jamkhandi city during 2016.The collected samples were washed with distilled water to remove the dust particles. Then samples were cut into small pieces using a clean knife. Edible portions of the samples were used for analysis; the leafy vegetables included Spinach (Palak), Fenugreek (Methi), Radish(Mulangi),Deccan hemp(Pundi), Coriander (Kotambari) and Dill(Sabasagi).All the samples were collected and stored in polyethene bags until analysis under refrigeration condition $\left(<10^{\circ} \mathrm{C}\right)$. The samples for analysis were then dried using the oven dry method at $105^{\circ} \mathrm{C}$ for 24 hours (AOAC, 1990), and a mixture grinder was used to powder the samples while preventing oven heating.

About $1 \mathrm{~g}$ of the samples were weighed and digested in a mixture of $5 \mathrm{ml}$ of $\mathrm{HCl}, 2 \mathrm{ml}$ of $\mathrm{Conc}_{2} \mathrm{SO}_{4}$ and $20 \mathrm{ml}$ of Conc. $\mathrm{HNO}_{3}$ in a conical flask under a fume hood. The content was mixed and heated gently at $180^{\circ} \mathrm{C}-220^{\circ} \mathrm{C}$ for about $30 \mathrm{~min}$ on a hot plate. The content was heated until dense white fumes appear. It was then heated strongly for about $30 \mathrm{~min}$ then allowed cooling before making up to the mark in $50 \mathrm{ml}$ volumetric flask. This digested solution used to determine the micro-nutrients like Cadmium $(\mathrm{Cd})$, Chromium (Cr), Cobalt (Co), Copper ( $\mathrm{Cu})$, Iron (Fe), Lead (Pb), Manganese (Mn), Nickel (Ni) and Zinc (Zn)by using Atomic Absorption Spectrophotometer (Elico). The instrument setting and operational conditions were done in accordance with the manufacturers' specifications.

Plant samples and food grains used for analyses

\begin{tabular}{c|c|c|c}
\hline $\begin{array}{c}\text { Edible part of } \\
\text { vegetable / cereal }\end{array}$ & Common name & Botanical name & Family \\
\hline Leaf & Spinach (Palak) & Beta vulgaris L. & Chenopodiaceae \\
\hline Leaf & Fenugreek (Methi) & Trigonella foenum-graecum & Legumes \\
\hline Stem & Radis (Mulangi) & Raphanus sativus L. & Brassicaceae \\
\hline Leaf & Deccan hemp(Pundi) & Hibiscus cannabinus & Malvaceae \\
\hline Leaf & Coriander (Kotambari) & Coriandrum sativum & Umbelifers \\
\hline Leaf and stem & Dill (Sabasagi) & Anethum graveolens & Apiaceae \\
\hline Grain & Wheat & Triticum & Poaceae \\
\hline Grain & Jowar (Pure) & Sorghum bicolor & --- \\
\hline Grain & Jowar (Medium) & --- & - \\
\hline Grain & Sajji & -- & - \\
\hline
\end{tabular}

Table-1: Water quality parameters of selected spots and comparison with standards WHO, ISI, BIS. [S1-Hipparagi, S2-Surapali, S3-Savalagi and S4-Hirepadasalagi, Villages]

\begin{tabular}{c|c|c|c|c|c|c|c|c}
\hline S. No. & Parameters & $\mathrm{S}_{1}$ & $\mathrm{~S}_{2}$ & $\mathrm{~S}_{3}$ & $\mathrm{~S}_{4}$ & Average & WHO & ISI/BIS \\
\hline 1 & Temperature & 22 & 21 & 20 & 18 & 20 & --- & --- \\
\hline
\end{tabular}


RASĀYAN J. Chem. Vol. 10 | No. 1 |124-135 | January - March | 2017

\begin{tabular}{c|c|c|c|c|c|c|c|c}
\hline 2 & $\mathrm{pH}$ & 7.5 & 7.6 & 7.8 & 7.2 & 7.5 & $6.5-7.8$ & $6.5-8.5$ \\
\hline 3 & $\mathrm{EC}$ & 3470 & 1913 & 1827 & 1648 & 1652 & 400 & 1400 \\
\hline 4 & $\mathrm{TA}$ & 42.2 & 46.1 & 48.9 & 50.2 & 46.9 & 120 & $200-600$ \\
\hline 5 & $\mathrm{TH}$ & 48.5 & 52.6 & 49.2 & 40.5 & 47.7 & 300 & 300 \\
\hline 6 & $\mathrm{Na}^{+}$ & 32.5 & 31.2 & 38.5 & 40.2 & 35.6 & 200 & 200 \\
\hline 7 & $\mathrm{~K}^{+}$ & 10.2 & 8.9 & 9.2 & 10.0 & 9.6 & 1.4 & 1.4 \\
\hline 8 & $\mathrm{DO}$ & 6.5 & 6.6 & 6.6 & 6.6 & 6.6 & 7 & 7 \\
\hline 9 & $\mathrm{NO}_{3}$ & 45.3 & 41.2 & 40.5 & 38.5 & 52.7 & $40-100$ & $40-100$ \\
\hline 10 & $\mathrm{Cl}^{-}$ & 48.6 & 42.5 & 40.4 & 39.5 & 42.8 & $250-1000$ & 250 \\
\hline 11 & $\mathrm{SO}_{4}$ & 42.5 & 39.2 & 49.2 & 36.9 & 41.95 & $150-250$ & $150-200$ \\
\hline 12 & $\mathrm{Cr}$ & 0.1 & 0.1 & 0.1 & $\mathrm{ND}$ & 0.1 & 0.05 & 0.05 \\
\hline 13 & $\mathrm{Cu}$ & 0.5 & 0.4 & 0.5 & 0.5 & 0.5 & 2.00 & 2.00 \\
\hline 14 & $\mathrm{Fe}$ & 1.16 & 1.14 & 1.12 & 1.10 & 1.13 & $<1$ & 0.3 \\
\hline 15 & $\mathrm{Ni}$ & 0.05 & 0.06 & 0.06 & 0.05 & 0.06 & 0.02 & 0.02 \\
\hline 16 & $\mathrm{Cd}$ & 0.03 & 0.02 & 0.02 & 0.03 & 0.03 & 0.01 & 0.01 \\
\hline 17 & $\mathrm{~Pb}$ & 0.25 & 0.22 & 0.23 & 0.19 & 0.22 & 0.05 & 0.05 \\
\hline 18 & $\mathrm{Zn}$ & 7.2 & 7.6 & 6.8 & 7.0 & 7.2 & 5 & 5 \\
\hline 19 & $\mathrm{Mn}$ & 0.5 & 0.5 & 0.6 & $\mathrm{ND}$ & 0.5 & $>0.5$ & 0.3 \\
\hline 20 & $\mathrm{Ca}$ & 36.2 & 42.8 & 45.9 & 50.2 & 43.8 & $75-100$ & $75-100$ \\
\hline 21 & $\mathrm{TDS}$ & 1613 & 1012 & 931 & 856 & 1103 & $<500$ & 500 \\
\hline
\end{tabular}

Table-2: Physico-chemical parameters and other nutrients in soil samples of selected four locations $(\mathrm{mg} / \mathrm{kg}$ dried weight basis)[S1-Hipparagi and S2-Surapali, S3-Savalagi and S4-Hirepadasalagi, Villages]

\begin{tabular}{|c|c|c|c|c|c|c|c|}
\hline S.No & Parameter & UNIT & Spot $S_{1}$ & Spot $\mathrm{S}_{2}$ & Spot $\mathrm{S}_{3}$ & Spot $S_{4}$ & $\begin{array}{l}\text { Legal } \\
\text { limit }\end{array}$ \\
\hline $\mathrm{I}$ & \multicolumn{7}{|c|}{ Physical-Parameters } \\
\hline & Bulk Density & $\mathrm{g} / \mathrm{cc}$ & 1.14 & 1.11 & 1.11 & 1.12 & \\
\hline & $\begin{array}{l}\text { Water Holding } \\
\text { Capacity }\end{array}$ & $\%$ & 56 & 57 & 57 & 57 & \\
\hline & Texture & & Black & Black & Black & Black & \\
\hline II & \multicolumn{7}{|c|}{ Chemical Parameters } \\
\hline & $\mathrm{pH}$ & & 8.04 & 7.71 & 7.90 & 8.25 & $6.5-7.5$ \\
\hline & $\mathrm{EC}$ & $\mathrm{ds} / \mathrm{m}$ & 1.16 & 1.05 & 1.01 & 4.56 & $<1$ \\
\hline & Sodium & $\%$ & 0.51 & 0.62 & 0.25 & 0.84 & $<0.1$ \\
\hline & Calcium Carbonate & & Medium & Medium & Medium & Medium & \\
\hline III & \multicolumn{7}{|c|}{ Major Nutrients } \\
\hline & Organic Carbon & $\%$ & 1.08 & 0.98 & 2.08 & 0.95 & $0.5-0.75$ \\
\hline & Available N & $\mathrm{Kg} / \mathrm{h}$ & 310.2 & 269.3 & 278.6 & 259.3 & $250-280$ \\
\hline & Total N & $\%$ & 0.102 & 0.112 & 0.110 & 0.042 & $0.03-0.06$ \\
\hline & Available P & $\mathrm{Kg} / \mathrm{h}$ & 43.6 & 76.2 & 28.9 & 66.8 & $20-60$ \\
\hline & Available K & $\mathrm{Kg} / \mathrm{h}$ & 284 & 235 & 248 & 365.3 & $250-300$ \\
\hline IV & \multicolumn{7}{|c|}{ Secondary Nutrients } \\
\hline & $\mathrm{Ca}$ & $\%$ & 22.5 & 18.3 & 14.8 & 22.8 & $<1$ \\
\hline & $\mathrm{Mg}$ & $\%$ & 9.23 & 3.10 & 3.50 & 0.26 & $<0.5$ \\
\hline & $\mathrm{SO} 4$ & $\mathrm{ppm}$ & 18.6 & 5.12 & 12.3 & 17.3 & $10-20$ \\
\hline $\mathrm{V}$ & \multicolumn{7}{|c|}{ Micro Nutrients } \\
\hline & Iron $(\mathrm{Fe})$ & ppm & 4.51 & 4.41 & 3.41 & 3.21 & Min.4.50 \\
\hline & Manganese & ppm & 2.94 & 3.12 & 1.91 & 1.3 & Min.2.00 \\
\hline & Zinc (Zn) & ppm & 0.95 & 0.87 & 0.72 & 0.68 & Min.0.75 \\
\hline & Copper $(\mathrm{Cu})$ & ppm & 1.33 & 0.63 & 0.91 & 0.82 & Min.0.60 \\
\hline & Cadmium & ppm & 0.54 & 0.36 & 0.28 & 0.17 & Min. 0.2 \\
\hline & Chromium & $\mathrm{ppm}$ & 1.18 & 1.06 & 0.89 & 0.80 & Min. 0.02 \\
\hline & Lead & $\mathrm{ppm}$ & 0.10 & 0.09 & 0.08 & 0.10 & $0.05-0.2$ \\
\hline
\end{tabular}


RASĀYAN J. Chem.

Vol. 10 | No. 1 |124-135 | January - March | 2017

\begin{tabular}{c|c|c|c|c|c|c|c}
\hline & Nickel & ppm & 1.31 & 0.24 & 0.53 & 0.88 & Min. 0.50 \\
\hline & Boron & ppm & 0.95 & 0.68 & 0.78 & 0.88 & Min.0.50 \\
\hline & Molybdenum & $\mathrm{ppm}$ & 0.11 & 0.10 & 0.09 & 0.08 & $0.05-0.2$ \\
\hline
\end{tabular}

Table-3: Concentration of Heavy Metals (ppm dry weight) in Cereal Samples ofselected Lands.

\begin{tabular}{|c|c|c|c|c|c|c|}
\hline $\begin{array}{l}\text { Metal } \\
(\mathrm{ppm})\end{array}$ & Wheat & Jawar (Pure) & $\begin{array}{c}\text { Jawar } \\
\text { (Medium) }\end{array}$ & Sajji & $\begin{array}{r}\text { Tolerance } \\
\text { limit }(\mathrm{ppm})\end{array}$ & $\begin{array}{l}\text { WHO } \\
\text { Safe limit }\end{array}$ \\
\hline \multicolumn{6}{|c|}{ Cultivation lands of Hire Padasalagi village. } & \\
\hline Copper & 3.15 & 1.70 & 2.45 & 2.18 & 3 & --- \\
\hline Iron & 38.83 & 23.00 & 32.05 & 21.45 & 20 & --- \\
\hline Zinc & 333.75 & 195.50 & 172.25 & 232.25 & 27.4 & --- \\
\hline Manganese & 51.25 & 10.75 & 16.38 & 13.65 & 2 & 500 \\
\hline Cobalt & 0.14 & 0.11 & 0.13 & 0.15 & --- & 50 \\
\hline Nickel & 0.08 & 0.18 & 1.40 & 1.00 & 1.63 & 67 \\
\hline Chromium & 0.22 & 0.20 & 0.18 & 0.15 & 0.02 & 2.3 \\
\hline Lead & 0.09 & 0.08 & 0.065 & 0.054 & 0.2 & 0.3 \\
\hline Cadmium & ND & ND & ND & ND & 0.2 & 0.2 \\
\hline \multicolumn{6}{|c|}{ Cultivation lands of Savalagi village. } & \\
\hline Copper & 3.28 & 2.78 & 2.59 & 2.80 & 3 & --- \\
\hline Iron & 38.92 & 24.2 & 35.2 & 22.08 & 20 & --- \\
\hline Zinc & 341.12 & 197.51 & 173.98 & 233.10 & 27.4 & --- \\
\hline Manganese & 52.38 & 11.21 & 17.31 & 14.12 & 2 & 500 \\
\hline Cobalt & 0.24 & 0.18 & 0.12 & 0.25 & --- & 50 \\
\hline Nickel & 0.09 & 0.19 & 1.48 & 0.92 & 1.63 & 67 \\
\hline Chromium & 0.49 & 0.31 & 0.29 & 0.19 & 0.02 & 2.3 \\
\hline Lead & 0.110 & 0.100 & 0.072 & 0.061 & 0.2 & 0.3 \\
\hline Cadmium & ND & ND & ND & ND & 0.2 & 0.2 \\
\hline \multicolumn{6}{|c|}{ Cultivation lands of Hipparagi village. } & \\
\hline Copper & 4.15 & 3.75 & 3.82 & 3.54 & 3 & --- \\
\hline Iron & 39.9 & 25.9 & 38.91 & 26.2 & 20 & --- \\
\hline Zinc & 353.81 & 201.10 & 181.21 & 239.12 & 27.4 & --- \\
\hline Manganese & 55.40 & 13.92 & 19.12 & 17.21 & 2 & 500 \\
\hline Cobalt & 0.49 & 0.39 & 0.13 & 0.46 & --- & 50 \\
\hline Nickel & 0.11 & 0.25 & 1.55 & 1.08 & 1.63 & 67 \\
\hline Chromium & 0.85 & 0.42 & 0.331 & 0.19 & 0.02 & 2.3 \\
\hline Lead & 0.163 & 0.130 & 0.09 & 0.08 & 0.2 & 0.3 \\
\hline Cadmium & ND & ND & ND & $\mathrm{Nd}$ & 0.2 & 0.2 \\
\hline \multicolumn{6}{|c|}{ Cultivation lands of Surapali village. } & \\
\hline Copper & 3.98 & 3.01 & 3.12 & 3.12 & 3 & --- \\
\hline Iron & 39.1 & 24.9 & 36.2 & 24.5 & 20 & --- \\
\hline Zinc & 348.20 & 198.15 & 174.52 & 234.25 & 27.4 & --- \\
\hline Manganese & 53.92 & 12.91 & 17.98 & 15.20 & 2 & 500 \\
\hline Cobalt & 0.35 & 0.25 & 0.12 & 0.34 & --- & 50 \\
\hline Nickel & 0.10 & 0.23 & 1.50 & 1.01 & 1.63 & 67 \\
\hline Chromium & 0.68 & 0.49 & 0.39 & 0.21 & 0.02 & 2.3 \\
\hline Lead & 0.141 & 0.110 & 0.08 & 0.07 & 0.2 & 0.3 \\
\hline Cadmium & ND & ND & ND & ND & 0.2 & 0.2 \\
\hline
\end{tabular}

\section{RESULTS AND DISCUSSION}

The contaminated water used for irrigation was analyzed for temperature, turbidity, DO, $\mathrm{pH}, \mathrm{EC}$, TDS, TA, TH, Carbonates, bicarbonates, chloride, sulphate, calcium and heavy metals were reported in table 1. The results revealed that TDS, EC, K, Ni, $\mathrm{Cd}, \mathrm{Pb}, \mathrm{Zn}$ and $\mathrm{Fe}$ were found higher than the permissible limits given by the National Standards for drinking water quality. 
From the findings and by the fact that the soil at these sites contaminated with heavy metals found above permissible limits. The sites of Hipparagi and Surapali have been irrigated with polluted waste water (municipal sewage water) from Rabakavi and Banahatti industrialized and urbanized towns. Hence, the most prevalent heavy metals such as $\mathrm{Fe}, \mathrm{Mn}, \mathrm{Zn}, \mathrm{Cu}, \mathrm{Cd}$ and $\mathrm{Cr}$ in the soil samples found to be in higher concentrations as reported in Table 2.

Table 3 reports the results of heavy metals in wheat grains, Jawar (pure), Jawar (Medium) and Sajji from the cultivated lands of Hipparagi, Surapali, Savalagi and Hire Padasalagi villages, where the crops were irrigated with River Krishna amendments with municipal sewage waste, solid waste etc.,

\section{Heavy Metal Concentrations in Cereals \\ Copper $(\mathbf{C u})$}

Copper is one of the essential micronutrients in plants and animals ${ }^{21}$. The human body contains $\mathrm{Cu}$ at a level of 1.4 to $2.1 \mathrm{ppm}$ of body mass. $\mathrm{Cu}$ is absorbed in the intestine (gut), which facilitates iron uptake. Its deficiency can produce anemia- like symptoms, neutropenia, bone abnormalities, increased incidence of infections, and abnormalities in glucose and cholesterol metabolism. In the present investigation the concentration of $\mathrm{Cu}$ in the wheat grains was found to be in the range of $3.15 \mathrm{ppm}$ to $4.15 \mathrm{ppm}$ from all selected cultivated lands, the values were found higher than the tolerance limit, this is the indication that the soils of the region received a high metal load through the application of contaminated sewage water, solid wastes etc., the order of Copper concentration in wheat grains as compared with other cereals like Jawar (Pure), Jawar (Medium) and Sajji was as: Wheat > Jawar (Medium) > Jawar (Pure) > Sajji. From the investigation, it is revealed that the Copper concentration in wheat grains found more than other cereals.

\section{Iron $(\mathbf{F e})$}

Iron is an essential element in man and plays a vital role in the formation of hemoglobin, oxygen and electron transport in human body ${ }^{22}$. In the present investigation, Iron was found to have the highest concentration in the entire cereals samples analyzed (table 3). The maximum concentration of iron was found in wheat $(39.9 \mathrm{ppm})$ at Hipparagi cultivated irrigated lands. The tolerance limit of Iron in food is found to be $20 \mathrm{ppm}$. The results obtained in this study were higher than the recommended limit. The total accumulation of Fe was in the order of Wheat $>$ Jawar (Medium) $>$ Sajji $>$ Jawar (Pure). Hence, the study revealed that there was a significant difference in levels of $\mathrm{Fe}$ in the cereals.

\section{Zinc (Zn)}

Like Copper, Zinc is a most studied element in wheat grains, it is essential to all organisms and has an important role in metabolism, growth etc., $\mathrm{Zn}$ deficiency leads to coronary heart diseases and various metabolic disorders ${ }^{23}$. In the current study, the values of $\mathrm{Zn}$ was found to be in between $353.81 \mathrm{ppm}-$ $333.75 \mathrm{ppm}$. The highest value found in the wheat grains of Hipparagi cultivated lands, the lowest values found in the lands of Hire Padasalagi. The levels of $\mathrm{Zn}$ in other grains such as Jawar (Pure), Jawar (Medium) and Sajji were found to be $201.10 \mathrm{ppm}, 181.21 \mathrm{ppm}$ and $239.12 \mathrm{ppm}$ respectively from cultivated lands of Hipparagi locations; all values were higher than the prescribed range. It was evident from table 2 that deposition of heavy metal in soils by the uses of municipal waste water, sewage sludge etc., The content of Zinc reported in this investigation is generally higher than the permissible levels in all selected cultivated lands set by sttandards ${ }^{24}$. The study revealed that there was significant deference 5 ppm to $7 \mathrm{ppm}$ in levels of Zinc in all cereals.

\section{Manganese (Mn)}

Essential for many biochemical processes. Kidney and liver are the main storage places for the Mn in the body, $\mathrm{Mn}$ is essential for the normal bone structure, reproduction and Mn play very important role in the functioning of the central nervous system. The deficiency of Mn causes reproductivity failure in both male and female ${ }^{23}$. Mn found in maximum concentration in wheat at Hipparagi cultivated lands (55.40 ppm) and minimum in Jawar (Pure) (13.92 ppm) in the same area the concentration of $\mathrm{Mn}$ in the cereals were found in the order: Jawar (Pure) $<$ Sajji < Jawar (Medium) $<$ Wheat; as reported in Table-3. 


\section{Cobalt (Co)}

Cobalt is an important component of the vitamin B-12 molecule. It is required in the manufacture of RBC and in preventing anemia. An excessive intake of Cobalt may cause the over productionof $\mathrm{RBC}^{22}$. In the current study the maximum concentration of Cobalt found in wheat $(0.49 \mathrm{ppm})$ of Hipparagi cultivated lands and minimum value of Cobalt found $(0.13 \mathrm{ppm})$ in Jawar (Medium) of the same locations - the concentration of Cobalt in cereals samples were found in the order of Wheat $>$ Sajji $>$ Jawar (Pure) $>$ Jawar (Medium) respectively (Table 3). The same trends were seen in other selected region of irrigated lands.

\section{Nickel (Ni)}

Enzymes functions are purely depended on the presence of Nickel. The trace amounts of Ni may be beneficial to activate somebody systems, but its toxicity at higher levels is more enzyme prominent ${ }^{25}$. The present findings of $\mathrm{Ni}$ in selected cereals found in between $1.55 \mathrm{ppm}$ to $0.08 \mathrm{ppm}$ which is less than the tolerance limit in cereals (1.6 ppm). Ni in wheat grain is $0.11 \mathrm{ppm}$, which is under the permissible limit. The order of Ni levels in Hipparagi cultivated lands were recorded as: Jawar (Medium) > Sajji > Jawar (Pure) $>$ Wheat.

\section{Chromium (Cr)}

Chromium is an essential element required for normal sugar and fat metabolism even though chromium has been classified as not essential for mammals ${ }^{26}$. It is effective to the management of diabetes and it is a cofactor with insulin. $\mathrm{Cr}$ (III) and its derived compounds are not considered a health hazard, while the toxicity and carcinogenic properties of $\mathrm{Cr}(\mathrm{VI})$ have been known for a long time ${ }^{27}$. The concentration level of $\mathrm{Cr}$ in Hipparagi cultivation lands in wheat, Jawar (Pure), Jawar (Medium) and Sajji were found to be $0.85,0.420 .33$ and $0.19 \mathrm{ppm}$ respectively. These values are lower than the maximum permissible limit of $2.3 \mathrm{ppm}$ by $\mathrm{FAO} / \mathrm{WHO}^{24}$. The $\mathrm{Cr}$ content in wheat grains was found to be higher in almost all cases of selected cultivated lands as reported in table 3.

\section{Lead $(\mathbf{P b})$}

Lead toxicity is known to cause muscular, skeletal, neurological, reproductive and developmental effects $^{28}$. Higher concentrations of Lead reduce the growth, biomass and total chlorophyll content of plants. Consumption of cereals containing higher concentrations of Lead in the form diet may increase blood $\mathrm{Pb}$ levels with increases risk of anemia and neurological disorders. It is concluded that the increment of total solid heavy metals contents $(\mathrm{Cd}, \mathrm{Pb}, \mathrm{Zn}$, and $\mathrm{Cu})$ could enhance gains $\mathrm{Cd}$ accumulation and the increment of total soil $\mathrm{Zn}$ content may lower $\mathrm{Pb}$ accumulation in grains.

The current study reveals that the higher value of Lead in wheat grains $(0.163 \mathrm{ppm})$ of Hipparagi cultivation lands and ranging from $0.163 \mathrm{ppm}$ to $0.08 \mathrm{ppm}$ in all grains, this is the indication that the cultivated soils were irrigated by waste water or amended by sludge in the region of Hipparagi, the other three selected villages such as Surapali, Savalagi and Hire Padasalagi are away from the dumping spots of municipal sewage of Rabakavi and Banahatti towns into the River Krishna downstream.

\section{Cadmium (Cd)}

Cadmium is highly toxic non-essential heavy metal and it does not have a role in the biological process in living organisms. Even lower concentration of $\mathrm{Cd}$ in the food chain could be harmful to living organisms ${ }^{28}$. Cd poisoning in man could lead to anemia, renal damage, bone disorder and concern of lungs (Edward et al ., 2013). Cadmium usually added to the soil by the uses of phosphatic fertilizers and industrial wastes may have a detrimental effect on soil micro-organisms. On the analysis of soil samples of the study area the concentration of Cd metal found to be $1.18 \mathrm{ppm}, 1.06 \mathrm{ppm}, 0.89 \mathrm{ppm}$ and $0.80 \mathrm{ppm}$ in Hipparagi, Surapali, Savalagi and Hire Padasalagi cultivation lands respectively. As can be seen from the current study (table 3) Cd was not detected in any of the cereal samples in the study area. 


\section{RASĀYAN J. Chem.}

Vol. 10 | No. 1 |124-135 | January - March | 2017

\section{Heavy Metals in vegetables}

The heavy metal levels determined were based on plants dry weight. Levels of $\mathrm{Cu}, \mathrm{Zn}, \mathrm{Ni}$ and $\mathrm{Mn}$ were observed to be lowest in selected all vegetable samples, while the levels of $\mathrm{Fe}, \mathrm{Cd}$ and $\mathrm{Pb}$ were the highest. Heavy metals affect the nutritive values of agricultural materials and also have a deleterious effect on human beings. The results of the vegetable analysis showed that the level of $\mathrm{Pb}$ in all samples was in between $30.5 \mathrm{ppm}$ to $58.1 \mathrm{ppm}$. The Pb levels in vegetables were observed in the order of Sabasagi $>$ Palak $>$ Kotambari $>$ Pundi $>$ Mulangi $>$ Menthe.

\section{Cadmium (Cd)}

A non-essential element in all the samples analyzed, its level was observed varying in between $6.1 \mathrm{ppm}$ to $31.6 \mathrm{ppm}$. The order of $\mathrm{Cd}$ metal concentration in the selected green vegetables: Palak $(31.6 \mathrm{ppm})>$ Pundi $(14.5 \mathrm{ppm})>\operatorname{Kotambari}(12.4 \mathrm{ppm})>$ Menthe $(6.7 \mathrm{ppm})>$ Mulangi $(6.3 \mathrm{ppm})>$ Sabasagi $(6.1 \mathrm{ppm})$. All values found above the tolerance limit, definitely will cause a hazardous effect on human beings.

\section{Copper $(\mathbf{C u})$}

Copper is an essential micro- nutrient which functions as biocatalysts, required for body pigmentation in addition to $\mathrm{Fe}$. $\mathrm{Cu}$ maintains a healthy central nervous system if it is within tolerance limits. It prevents anemia and interrelated with the function of $\mathrm{Zn}$ and $\mathrm{Fe}$ in the body. In the current study the concentration of $\mathrm{Cu}$ in all the tested vegetable samples varied between $19.5 \mathrm{ppm}$ in Sabasagi to $45.2 \mathrm{ppm}$ in Mulangi. $\mathrm{Cu}$ levels in other green vegetables found to be as Palak (23.5 ppm), Menthe (44.5 ppm), Pundi (24.2 ppm) and Kotambari (25.7 ppm) all values were within the prescribed legal limits.

\section{Zinc (Zn)}

One of the most important metals for normal growth and development in a human being is Zinc ${ }^{29}$. Its deficiency may be due to inadequate dietary intake. The concentration of $\mathrm{Zn}$ in the samples reported in this study varied between $58.9 \mathrm{ppm}$ lowest in Sabasagi and $116.4 \mathrm{ppm}$ highest in Mulangi. Concentrations of $\mathrm{Zn}$ metal in other vegetables were found to be as: Palak (75.5 ppm), Menthe (73.0 ppm), Pundi (64.2 ppm) and Kotambari (69.0 ppm).

Table-4:Concentration of Heavy Metals in Green Vegetables (ppm values) available in Local Market Places.

\begin{tabular}{c|c|c|c|c|c|c|c|c}
\hline S. No. & Vegetable & $\mathrm{Cu}$ & $\mathrm{Zn}$ & $\mathrm{Ni}$ & $\mathrm{Mn}$ & $\mathrm{Fe}$ & $\mathrm{Pb}$ & $\mathrm{Cd}$ \\
\hline 1 & $\begin{array}{c}\text { Palak } \\
\text { (Spinach) }\end{array}$ & 23.5 & 75.5 & 12.7 & 174.0 & 1120.0 & 51.4 & 31.6 \\
\hline $\begin{array}{c}\text { Menthe } \\
\text { (Trigonella) }\end{array}$ & 44.5 & 73.0 & 23.0 & 93.0 & 470.0 & 30.5 & 6.7 \\
\hline 3 & $\begin{array}{c}\text { Mulangi } \\
\text { (Radish) }\end{array}$ & 45.2 & 116.4 & 13.8 & 51.2 & 841.7 & 34.6 & 6.3 \\
\hline 5 & $\begin{array}{c}\text { Pundi (Deccan } \\
\text { henp) }\end{array}$ & 24.2 & 64.2 & 16.4 & 46.4 & 541.8 & 41.4 & 14.5 \\
\hline 6 & $\begin{array}{c}\text { Kotambari } \\
\text { (Coriander) }\end{array}$ & 25.7 & 69.0 & 11.8 & 162.0 & 424.5 & 49.5 & 12.4 \\
\hline \multicolumn{2}{c|}{ Sabasagi (Dill) } & 19.5 & 58.9 & 13.6 & 39.9 & 421.0 & 58.1 & 6.1 \\
\hline \multicolumn{2}{c|}{ WHO Safe limit } & 50 & 300 & 50 & 300 & 270 & 10 & 3 \\
\hline
\end{tabular}

\section{Nickel (Ni)}

Nickel plays some role in body functions including enzymes functions. It occurs naturally more in plants than in the animal flesh. It activates some enzymes systems in trace amount but its toxicity at higher levels in more prominent. The Ni levels in the samples tested varied between $11.8 \mathrm{ppm}$ and $23.0 \mathrm{ppm}$ with the lowest level observed in Kotambari (11.8 ppm) and highest observed in Menthe (23.0 ppm). 


\section{Manganese (Mn)}

Manganese has little direct activity on its own in the body as it is an integral component of Vitamin $\mathrm{B}_{12}$. The activity and its uses to the body system are similar to that of Vitamin B12. However, in this study its level varied between 39.9 ppm lowest in Sabasagi and $174.0 \mathrm{ppm}$ highest in Palak. Menthe (93.0 ppm), Mulangi (51.2 ppm), Pundi (46.4 ppm) and Kotambari (162.0 ppm). The metal ion found within the safe limit in all the green vegetables.

\section{Iron $(\mathbf{F e})$}

Iron metal concentration in selected all vegetable samples found more than the tolerance and safe legal limit. Its concentration found highest in Palak (1120.0 ppm) and lowest in Sabasagi $(421.0 \mathrm{ppm})$. The order of the Fe in all vegetables were recorded as: Palak $(1120.0 \mathrm{ppm})>$ Mulangi $(841.7 \mathrm{ppm})>$ Pundi $(541.8 \mathrm{ppm})>$ Menthe $(470.0 \mathrm{ppm})>\operatorname{Kotambari}(424.5 \mathrm{ppm})>$ Sabasagi $(421.0 \mathrm{ppm})$.

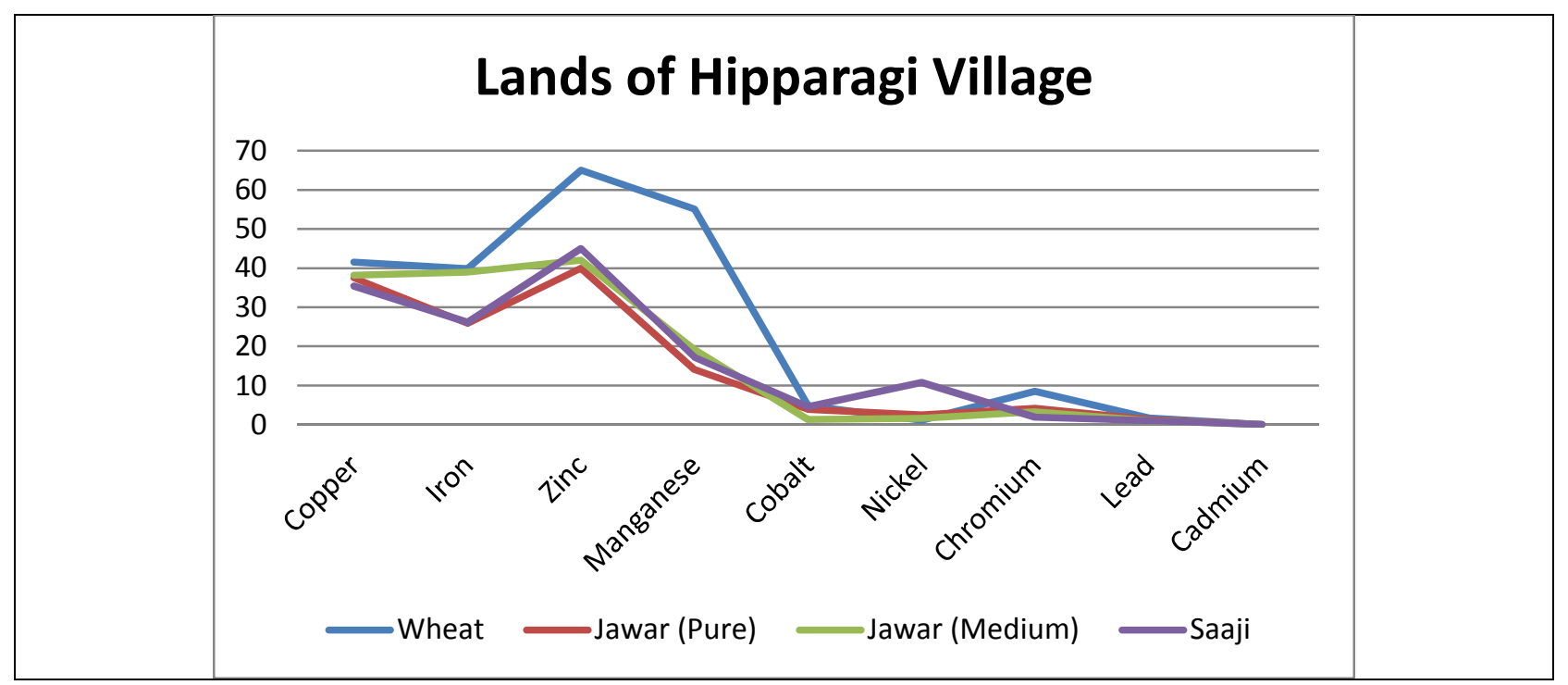

Fig.-1.Heavy Metals (ppm dry weight) in Cereals samples of Lands of Hipparagi Village.

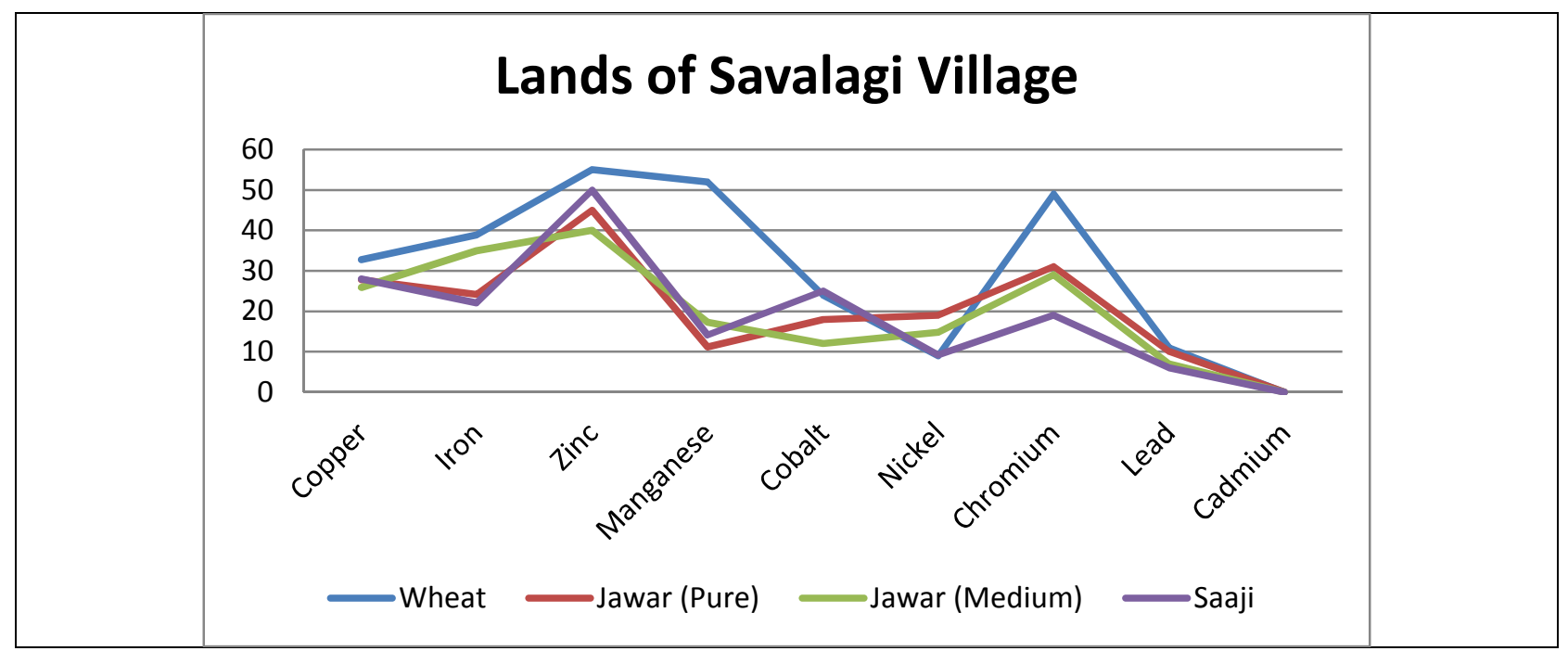

Fig.-2. Heavy Metals (ppm dry weight) in Cereals samples of Lands of Savalagi Village. 


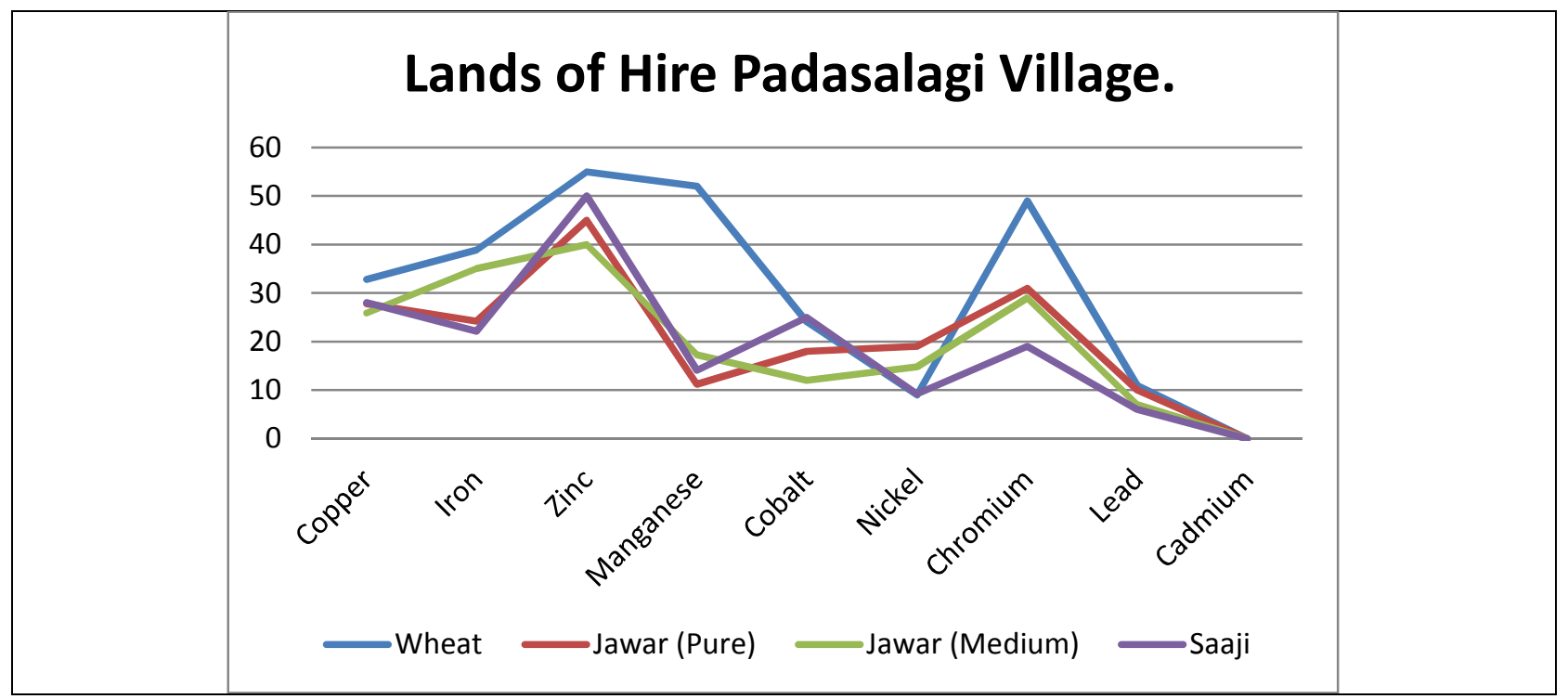

Fig.-3. Heavy Metals (ppm dry weight) in Cereals samples of Lands of Hire Padasalagi Village.

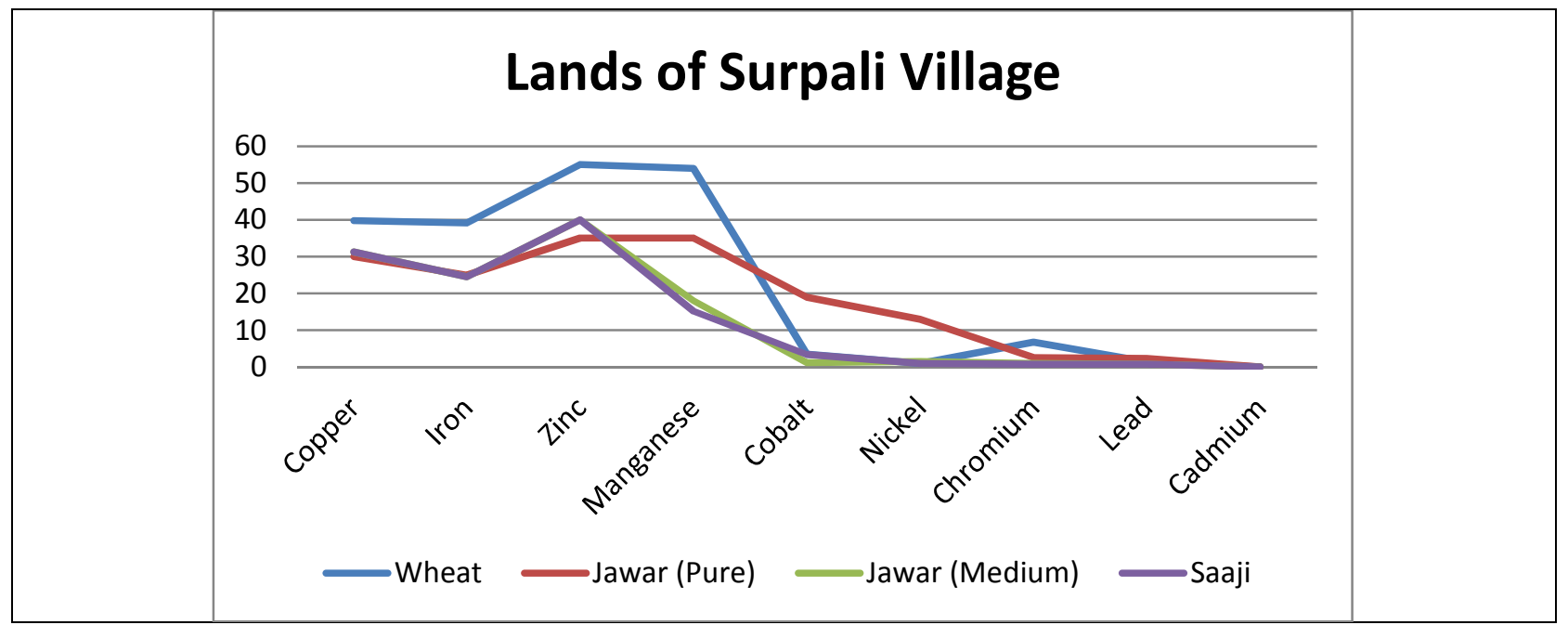

Fig.-4. Heavy Metals (ppm dry weight) in Cereals samples of Lands of Surpali Village.

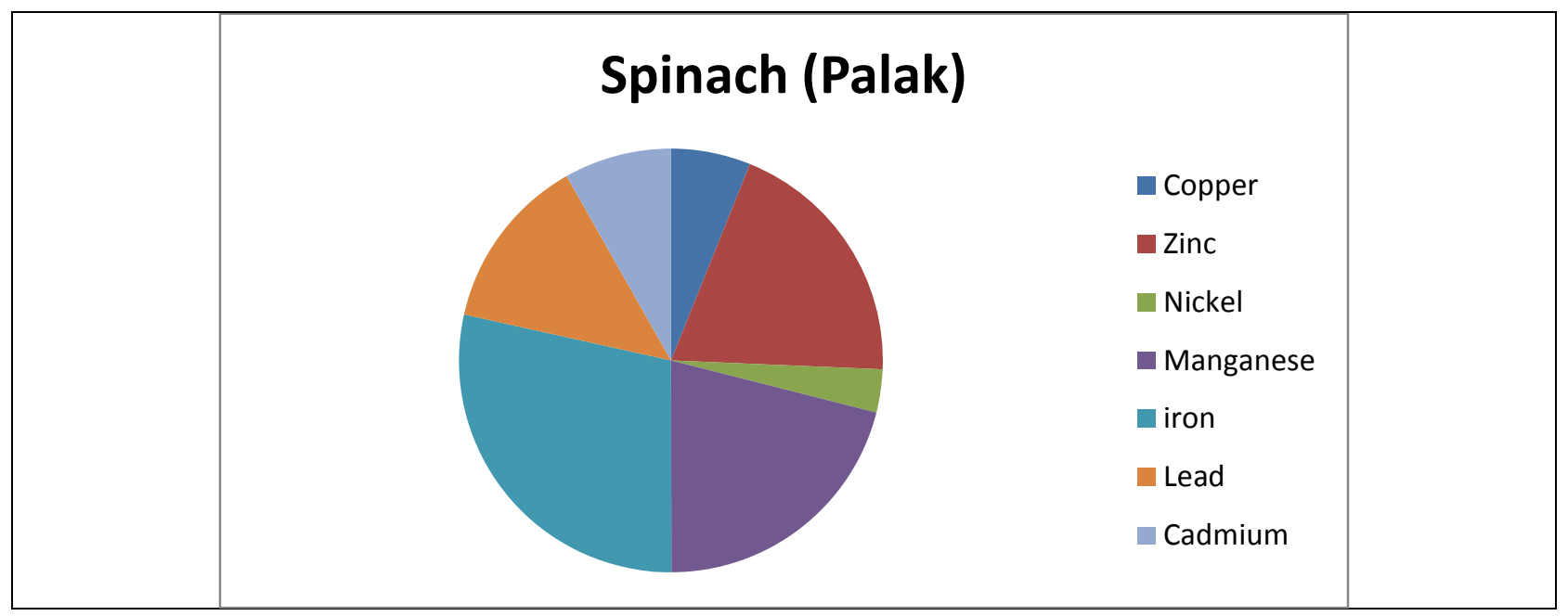

Fig.-5. Heavy Metals in Spinach (Palak) Green Vegetable (ppm value). 
RASĀYAN J. Chem.

Vol. 10 | No. 1 |124-135 | January - March | 2017

\section{CONCLUSION}

Analysis of heavy metal concentrations in cereals grown in soils of four selected villages irrigated with River Krishna water. The cultivation lands of Hipparagi is located nearer to the dumping spot $(0.5 \mathrm{~km})$ of municipal wastes / sewage wastes from Rabakavi and Banahatti Urbanized and Industrial towns to the stream of the river. In addition to this forming community were using fertilizers, pesticides for growing these cereals. Hence, the soil will be affected by the accumulation of these heavy metals. Most of the metals found in Wheat and Jawar grains were higher than the International standards. The villages like Surapali (4kms), Savalagi $(8 \mathrm{kms})$ and Hire Padasalagi $(11 \mathrm{kms})$ away from the municipal waste dumping spot. But, the heavy metal concentrations in the food grains (cereals) of the cultivation lands of these regions were found in higher ranges were due to agricultural practices, uses of fertilizers and pesticides. $\mathrm{Zn}, \mathrm{Fe}, \mathrm{Cu}$ in food grains in the current study of Hipparagi cultivated lands were found above the safe limit. Whereas $\mathrm{Mn}, \mathrm{Co}, \mathrm{Ni}, \mathrm{Cr}, \mathrm{Pb}$ and $\mathrm{Cd}$ were under the safe limits. The farming community of Hipparagi village and authorities of the municipal council of Rabakavi and Banahatti were informed and recommended that municipal waste water treatment must be carried out prior to dumping directly or indirectly into the stream of the river to avoid soil and food grains toxicity by heavy metals. The results reported here confirm that the vegetables collected from chosen production and marketplaces in the Jamkhandi city contained heavy metal contents within the safe limits prescribed by the WHO. But Lead, Cadmium and Iron exceeded the tolerance level. The concentration of Iron in Palak $1220.0 \mathrm{ppm}$, the concentration of Cd in Palak $31.6 \mathrm{ppm}$ and the concentration of Lead in Sabasagi $58.1 \mathrm{ppm}$ were highest and exceed the tolerance limit. The heavy metal concentration in available vegetables leads toxic effect to body system and causing health hazards.

\section{Conflict of interest}

It is quite necessary to educate the farming community providing information's, suggestions about the soil properties, recommendations made for proper uses of fertilizers and pesticides. The municipal authorities informed to go for proper treatment of municipal sewage water before dumping into the water stream. Formers were encouraged to reduce soil contamination by controlling the uses of fertilizers, pesticides.

\section{ACKNOWLEDGEMENT}

Authors express their sincere thanks to Dr. C.N.R. Rao, FRS National Research Professor, Chairman Vision Group on Science and Technology, Bangalore. The authors are also thankful to Dr. B.G.Mulinami former Vice-Chancellor and chief Administrative Officer, BLDE'S Association Vijaypur, authors are very grateful to Prof: S.H.Lagali Administrative Officer BLDE'S Association Vijaypur and Principal Dr. S. C. Hiremath for providing necessary facilities required to carry out this research work.

\section{REFERENCES}

1. Marshall, Enhancing food chain integrity: quality assurance mechanism for air pollution impacts on fruits and vegetable systems. Crop Post-Harvest Program, Final Technical Report (R7530), 2004.

2. S. Khan, Q. Cao, Y.M. Zheng, Y.Z. Huang, Y.G. Zhu, Environmental Pollution, 152(3), 686 (2008).

3. M.A. Radwan, A.K. Salama,Food Chem. Toxicol.,44, 1273(2006).

4. A. Maleki, M.A Zarasvand, Asian Journal of Tropical Medicine and Public Health, 39 (2), 335(2008).

5. C.S.C. Wong, X.D. Li, G. Zhang, S.H. Qi, X.Z Peng, Atmospheric Environment,37(7), 670 (2003).

6. R.K Sharma,.M. Agrawal, F.M Marshall, Bulletin of Environment Contamination and Toxicology, 77, 311 (2006).

7. M. Qadir, A. Ghafoor, G. Murtaza, Environ. Dev. Sustainability, 2, 13(2000).

8. A. Singh, R.K Sharma, M. Agrawal, F.M. Marshall, Food Chem. Toxicol., 48, 611(2010).

9. F. Mapanda, E.N. Mangwayana, J. Nyamangara, K.E. Giller, Ecosystem. Environ., 107, 151(2005).

10. B. Gebregziabher, S . Tesfaye,Int. J. Innov. Appl. Stud., 7(1), 78(2014).

11. D.J. Haware, H.P. Pramod,Int. J. Res. Chem. Environ.,4(3), 163(2014).

12. C.K. Bempah,A.B Kwofie,.A.O. Tutu,D. Denutsui,N. Benti,Elixir Pollut.,39,4921(2011).

13. C.A. Edem, G. Iniama, V. Osabor,R. Etiuma, M. Occhelebe,Pak. J. Nut.,8(5), 585(2009). 
RASĀYAN $J$. Chem.

Vol. 10 | No. 1 |124-135 | January - March | 2017

14. M.K. Turkdogan,F. Lilicel, K.Kara, I.Tuncer, I Uygan., Environ. Toxicol. Pharmmacol.,13(3), 175(2003).

15. WHO (1992). Cadmium, Environmental Health Criteria, Geneva.,Vol. 134.

16. L Jarup., Br. Med. Bull.,68, 167(2003).

17. C.H Pitot, P.Y.Dragan, Toxicology Inter. Edi. McGraw Hill, New York, pp. 210-260, (1996)

18. O.P. Sobukola, O.U.Dairo,Food J., 25(1), 145(2007).

19. D’Mello JPF, CABI publishing, Wallingford, Oxon, UK, Cambridge, M. A. p. 480, (2003).

20. M.I. Zaidi, A .Asar, A .Mansoor, M.A. Farooqui, J. Appl. Sci.,5(4), 708(2005).

21. I. Hussain, M.A. Khan, J.Ali, J. Che. Soc. Pak., 33, 499(2011).

22. I.A. Kalagbor, V. Barisere, G. Barivule, S. Barile, C. Bassey,Res. J. Environ. Earth Sci.,6(1), 18 (2014).

23. A Saraf, A. Samant, Int. J. Pharma. Sci., 3(3), 229(2013).

24. FAO/WHO, Codex Alimentarius Commission (2001). Food additives and contaminants. Joint FAO/WHO food standards programme, ALINORM 01/12A: 1-286.

25. P.C. Onianwa, J.A. Lawal, A.A.Ogunkeye, B.M. Orejimi,J. Food. Comps. Anal., 13,961 (2000).

26. K.R. DI-Bona, S. Love, N.R. Rhodes, D. Mcadory, S.H.Sinha, N. Kern, J. Kent, J.F. Rasco, J.B. Vincent,J. Biol. Inorg Chem.,16,381(2011).

27. I. Kalagbor, E.Diri,Int. Res. J. Public Environ. Heal., 1(4),87(2014).

28. G. Ambedkar, M. Muniyan, Int. J. Toxicol. Appl. Pharmacol., 2(2), 25(2012).

29. N.G. Sathawara, D.J. Parikish, Y.K.Agarwal,Bull. Environ. Cont. Toxicol., 73,756(2004).

[RJC-1575/2017] 